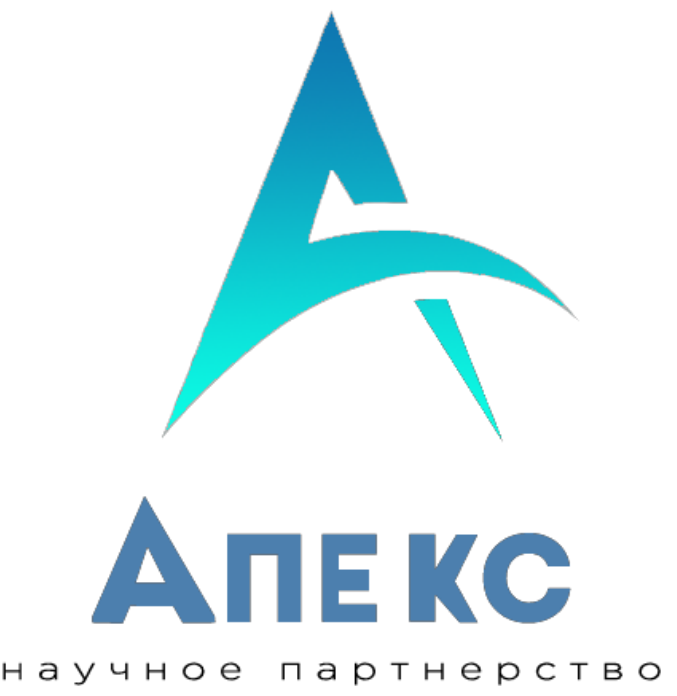

\title{
НОВЫЙЭТАПРАЗВИТИЯНАУКИ
}

Сборникстатейпоматериаламмеждународнойнаучнопрактическойконференции7апреля2017г.

г. Калининград 
ОЦЕНКА ГЕТЕРОЗИСНОГОЭФФЕКТА У ГИБРИДОВРЕДЬКИЕВРОПЕЙСКОЙЛЕТНЕЙ

КосенкоМ.А.

К.с.-Х. н., старшийнаучныйсотрудникВНИИО,Верея, Россия

Аннотация:встатьерассмотреныосновныенаправлениявселекцииредькиевр опейскойлетней.Проведенаоценкагетерозисныхгибридовпоурожайности,товарно сти, форме.

Ключевыеслова:редькаевропейская,гетерозис,урожайность,инбредныелин ии,товарность, коэффициент вариации.

Дляполучениягибридовкрестоцветныхкультурсхемыселекционногопроцес сапредусматриваютиспользованиеспорофитнойфизиологическойсамонесовмест имостиилицитологическоймужскойстерильности.

Материаломисследованийслужили 18 самонесовместимыхлинийредькиевро пейскойлетней,отобранныхидоведенныхдо3-

4инбридинга,из3коллекционныхсортов отечественногои зарубежногопроисхождения.

Выборпризнаковиточностьихоценкивомногомопределяетэффективностьв ыделениялучшихрастений-родоначальниковбудущихпотомств,аэтокачествоматериаланаследующихэтапахселекционногопроцесса[1, с.17].

Редькаевропейскаяурожайна,холодостойка,приспособленакусловиямдлинн огодняидлительногохранения.Однимизпроверенныхспособовповышенияурожай ностииполученияоднородной,качественнойпродукцииявляетсяиспользованиегиб риднойсилырастения(гетерозиса) [5, с.23].

Урожайностьинбредныхлиний4гопоколенияварьировалаот 1,27до2,96кг/м². Числотоварныхкорнеплодовварьировалоот 49,0до100,0\%.

Многочисленнымиисследованиямиустановлено,чтостепеньгетерозисаувел ичиваетсясуменьшениемгенетическогосходствамеждудвумяродителями.Онвыра женумногихмежвидовыхирядамежсортовыхгибридов,однаколучшиерезультатыд аютопределенныесочетанияинбредныхлиний,полученныхпринаправленнойселек циинакомбинационнуюспособностьпохозяйственнополезнымпризнаками биологическимсвойствам[3, с.27].

Инбридинг,особеннодлительный,наряду сположительнымимоментами,как, 
например,повышениекоэффициентавыравненностипопризнакам 
корнеплода, имеет и свои отрицательные стороны. Негативное влияниеинбридингахарактеризуетстепень инбреднойдепрессии.

Степеньинбреднойдепрессиипопризнакусреднеймассыкорнеплодауинбред ныхлиний $\mathrm{I}_{4}$, редькиевропейскойлетнейварьировала от0,082до-0,379.

Второйпосевгибридногоматериалаисамонесовместимыхлинийбыл произведенпопринятойсхеме20х10.

Поформекорнеплодылинийраспределилисьна:округлую-80,0\%,овальную20,0\%.УгетерозисныхгибридовF1:цилиндрическую- 28,5\%,овальную - 9,5\%, округло-овальную -23,8\% округлую-38,2\%.

Коэффициентвариациидлиныкорнеплодауинбредныхлинийколебалсяот0,2 до17,6\%.Коэффициентвариациидиаметракорнеплодаинбредныхлиний4гопоколенияизменялсяот 8,6 до15,4\%.Коэффициентвариациииндексформыизменя лсяот 12,1до25,1\%.

КоэффициентвариациидлиныкорнеплодагетерозисныхгибридовF1колебал сяот0,5до34,6\%.Коэффициентвариациидиаметракорнеплодаинбредныхлинийнах одилсявпределахот0,3до44,4\%.Коэффициентвариациииндексформыизменялсяот 6,0до25,8\%.

Конечнымрезультатомсельскохозяйственногопроизводстваявляетсявалова япродукция.Важноезначениеимеетуровень товарности[4, с.14].

Уровеньтоварностиуинбредныхлиний4гопоколенияварьировалот49,4до92,3\%.Уровеньтоварностиугетерозисныхгибрид овF1составлялот61,8до100\%.Массатоварногокорнеплодауинбредныхлиний4гопоколенияварьировалаот 22,0 до39,6г.Урожайностькорнеплодовнаходиласьвпределахот 1,10до1,98кг/м².

МассатоварногокорнеплодаугетерозисныхгибридовF1изменяласьот 15,0до 56,6г. Урожайность корнеплодов различаласьот0,75до2,83кг/м².

Производствогетерозисныхгибридов $F_{1}$ имеетфундаментальноезначение в современномовощеводствекак в отношенииповышенияурожайностии качества выращиваемойпродукции, таки получаемойприбыли[2, с.16].

Намибылоопределенопроявлениеэффектовгетерозисаугибридовпервогопо коленияредькиевропейскойлетней.Внекоторыхгибридныхкомбинацияхпроисход илоотрицательноепроявлениегетерозиса.Онварьировалот -100,0до157,3\%. 
Врезультатепроведениядвухсроковпосевабыловыявлено,чтов 1 срокуро жайностьнаходиласьвпределахот 1,42до2,96кг/м ${ }^{2}$,аво2срокизменялась от1,10до1,98кг/ $\mathrm{M}^{2}$.

\section{Список использованныхисточников:}

1.Косенко М.А. ХозяйственноценнаяхарактеристикасамонесовместимыхлинийредькиевропейскойлетнейВ сборнике:ПерспективыразвитиянаукииобразованияСборникнаучныхтрудовп оматериаламМеждународнойнаучнопрактическойконференции:в8частях.ООО "АР-Консалт".2015.С.17-18.

2.КосенкоМ.А.,ЛеуновВ.И.Возделываниередькилетнейевропейскогоп одвида в защищенноми открытомгрунтеГавриш.2011.№ 5. С.16-19.

3.КосенкоМ.А.,ЛеуновВ.И.Созданиелинийдляполучениягетерозисных гибридовредькинаосновесамонесовместимостиКартофельиовощи. 2011.№ 8 . C.27.

4.КосенкоТ.Г.Методическиеуказаниядлявыполнениякурсовыхработпо организациипроизводстваипредпринимательствувАПКстудентамиагрономи ческихспециальностейп. Персиановский, 2014.

5.КосенкоТ.Г.,КосенкоМ.А.Организацияэффективнойселекционнойра боты.Успехисовременнойнаукииобразования.2015. №3. С.23-25. 